\title{
Molecular Characterization of Aerobic Heterohophic Bacteria Isolated from Petroleum Hydrocarbon Polluted Brackish Waters of Bodo Creeks, Rivers State Nigeria
}

\author{
Tersagh Ichor, Phillip O. Okerentugba, Gideon C. Okpokwasili \\ Department of Microbiology, University of Port Harcourt, Choba, Nigeria \\ Email: smartichor2012@gmail.com
}

Received 23 July 2014; revised 23 August 2014; accepted 30 August 2014

Copyright @ 2014 by authors and Scientific Research Publishing Inc.

This work is licensed under the Creative Commons Attribution International License (CC BY). http://creativecommons.org/licenses/by/4.0/

\section{(c) (i) Open Access}

\begin{abstract}
Surface water sources in the oil producing Niger Delta region of Nigeria are highly susceptible to pollution by petroleum hydrocarbons and so it is important to understand the microbial diversity of such ecosystems. Water and sediment samples were collected between April-August, 2013 from Bodo creeks and taken to Environmental Microbiology laboratory of University of Portharcourt for analysis. A total of thirty aerobic heterotrophic bacterial strains isolated ranged from 3.0 - 7.0 $\times 10^{4} \mathrm{cfu}$ for surface water and $1.6-5.6 \times 10^{4} \mathrm{cfu}$ for sediment samples of Bodo creek using serial dilution and spread plate technique. Pure cultures of bacteria were obtained on the basis of their morphological characteristics and subjected to biochemical tests and further classified on the basis of 16S rRNA gene sequence analysis. The DNA was isolated from size fractionated samples and the diversity of bacteria in each fraction was studied using PCR amplification of partial 16S rRNA. The sequences were submitted to NCBIGen bank for identification and assigning of accession numbers. The isolated aerobic heterotrophic bacteria belong to the families of Enterobacteriaceae, Bacilliceae, Alcaligenaceae, Pseudomonadaceae, Flavobactericeae and Planococcaceae.
\end{abstract}

\section{Keywords}

Petroleum Hydrocarbon, Brackish Water, Aerobic Heterotrophic Bacteria, Diversity

\section{Introduction}

Bacteria are said to be ubiquitous with the capacity to colonize any habitat of the planet, having a greater active 
biomass compared to any other group of organism. The main reason for this ubiquitousness is their large surface area to volume ratio which gives them the ability to out-compete other microbes for dissolved compounds. They are metabolically diverse and can obtain energy from oxidizing carbon, parasitism, chemoautotrophy and photoautotrophy. They play a major role in most biogeochemical cycling of nitrogen, carbon, sulphur and oxygen in aquatic ecosystems [1] [2].

Various types of bacteria have been identified in different environments at different conditions [1]. With the exception of cyanobacteria, all other identified groups of bacteria are heterotrophic and do not contribute to primary production in the ecosystem but rather assimilate dissolved organic matter. Most bacteria species from the natural environment are reportedly difficult to identify with phenotypic methods commonly applied in clinical laboratories [3] hence the use of 16SrDNA based identification provides a better alternative to the phenotypic characterization methods [4] [5].

Large amounts of hydrocarbon contaminants are released into the environment as a result of human activities and are said to pose severe, immediate and long term ecological and environmental repercussion since a lot of the hydrocarbon components are toxic and persistent in terrestrial and aquatic environment [6]. Irrespective of these effects, several studies have isolated and identified bacteria species from different surface water sources contaminated with hydrocarbons [7]-[13]. Betrand et al. [14] isolated from interface water sediments a strain of halophilicarcheon, Harloacula villismortis. Other hydrocarbonoclastic halophilic and halotolerant microorganisms have been isolated from chronically hydrocarbon impacted sites and petroleum industry facilities [15]-[18].

Bodo creek, located in Bodo community of Gokana LGA of Rivers State is characterized by brackish water system and has been a site for oil industry operations since 1950 with varying degrees of petroleum hydrocarbon pollution. The aim of the present study was to isolate and identify aerobic heterotrophic bacteria from brackish waters of hydrocarbon polluted Bodo creeks and to produce their biochemical, physiological and molecular characterization and identification. The research provides updated information on the bacterial diversity of a petroleum hydrocarbon contaminated brackish surface water source which underscores the relevance of the study.

\section{Materials and Methods}

\section{Sampling Isolation and Growth Conditions}

Petroleum hydrocarbon polluted water (measured by total petroleum hydrocarbon using agilent 6890 GC-FID, TPH $769 \mathrm{mg} / \mathrm{L}$ ) and sediments samples (TPH $1109 \mathrm{mg} / \mathrm{kg}$ ) were collected from Bodo creeks in Bodo community of Gokana LGA. Ogoniland covers about $1000 \mathrm{~km}^{2}$ in Rivers state and has been the site for oil industry operations since 1950. The samples were collected from April to August, 2013 under sterile conditions using NiskinPvc water sampler at a distance of 50 metres distance apart and $20 \mathrm{~m}$ from the coast at five designated points and transported immediately to Environmental Microbiology Laboratory of the University of Portharcourt for isolation procedures. The bacteria were isolated using serial dilution method as described by Cheesebrough [19], with distilled water and the $10^{-3}$ dilution was considered and the duplicate of it plated on nutrient agar (oxoid) medium using spread plate technique. The nutrient agar comprises of the following in gm/litre; yeast extract 4.0 , tryptone 5.0 , glucose 50.0 , potassium dihydrogen phosphate 0.55 , potassium chloride 0.425 , calcium chloride 0.125 , magnesium sulphate 0.125 , Ferric chloride 0.0025 , manganese sulphate 0.0025 , bromocresol green 0.022 and Agar 15.0 with a pH $5.5 \pm 0.2$. Incubation of the resulting inoculated plates was done at about $37^{\circ} \mathrm{C}$ which is the mean temperature of the sites where samples were collected for $24 \mathrm{~h}$ and counted, the resulting mean from the duplicate was taken as the colony forming unit of the sample. Pure cultures of the resulting morphologically distinct colonies were singly isolated and plated on the same nutrient agar medium and incubated for another $24 \mathrm{~h}$ after which the isolates were inoculated in bijou bottles containing the growth medium and sent for molecular characterization.

The physicochemical parameters: electrical conductivity, turbidity, salinity, total organic carbon, phosphate, nitrate, total nitrogen and sulphate content of the samples were analysed as described by [20].

\section{Morphological, Biochemical and Physiological Characteristics}

Morphology of cells of the isolated strains was examined by light microscopy using Gram stain technique of 24 - $48 \mathrm{~h}$ old cultures grown on nutrient agar medium (oxoid) as described by Cheesebrough [19]. The physio- 
logical tests carried out were: catalase and oxidase reactions [21], utilization of lactose and glucose formation of gas from glucose, production of indole, MR and VP and Motility test [22] [23]. The tests were read after incubation for $24-48 \mathrm{~h}$ at room temperature.

\subsection{Extraction of DNA Using CTAB Method}

Bacterial cells of each isolate grown overnight in $10 \mathrm{~mL}$ of nutrient agar broth medium and shaken at room temperature was collected in Eppendorf tube by centrifugation at 14,000 rpm for 2 mins at room temperature. DNA was extracted from the pellet by suspending in $600 \mu \mathrm{L}$ of $2 \times \mathrm{CTAB}$ buffer incubated at $65^{\circ} \mathrm{C}$ for 2 mins. The DNA pellet was finally resuspended in $100 \mu \mathrm{L}$ of sterile distilled water. DNA concentration of the samples was measured on spectrophotometer at $260 \mathrm{~nm}$ and $280 \mathrm{~nm}$ and the genomic purity were determined. The genomic purity ranged between 1.8 - 2.0 for all the DNA samples as described by [24].

Agarose gel electrophoresis was used to determine the quality and integrity of the DNA by size fractionation on $1.0 \% \mathrm{w} / \mathrm{v}$ agarose gels supplemented with ethidium bromide $(0.5 \mu \mathrm{g} / \mathrm{mL} 0.5 \times \mathrm{TBE}$ buffer solution as described by [24].

\subsection{PCR Analysis of 16S rRNA Gene}

PCR analysis was run with a universal primer for bacteria and fungi called 16S. The universal primers used for bacteria were Eub 27F (5 $5^{1}-3^{1}$. AGA GTT TGA TCC TGG CTC AG) forward primer and Eub $1492 \mathrm{R}\left(5^{1}-3^{1}\right.$. ACG GCT ACC TTG TTA CGA CTT) for reverse primers [25]. The PCR mix comprises of $11 \mu \mathrm{L}$ of $10 \times$ buffer, $0.4 \mu \mathrm{L}$ of $50 \mathrm{mM} \mathrm{MgCl}_{2}, 0.5 \mu \mathrm{L}$ of $2.5 \mathrm{mM}$ dNTPs, $0.5 \mu \mathrm{L} 5 \mathrm{mM}$ Forward primer, $0.5 \mu \mathrm{L}$ of $5 \mathrm{mM}$ Reverse primer, $0.05 \mu \mathrm{L}$ of 5 units/ $\mu \mathrm{L}$ Taq DNA polymerase; $5 \mu \mathrm{L}$ template DNA and $5.05 \mu \mathrm{L}$ of distilled water to make up $10 \mu \mathrm{L}$ reaction mix.

The PCR profile used is initial denaturation temperature of $94^{\circ} \mathrm{C}$ for 3 mins, followed by 30 cycles of $94^{\circ} \mathrm{C}$ for $60 \mathrm{sec}, 56^{\circ} \mathrm{C}$ for $60 \mathrm{sec}$, and the final extension temperature of $72^{\circ} \mathrm{C}$ for 5 mins and then $10^{\circ} \mathrm{C}$ hold forever.

The amplicon was further purified before the sequencing using $2 \mathrm{M}$ Sodium Acetate wash techniques. To about $10 \mu \mathrm{L}$ of the PCR product, we added $1 \mu \mathrm{L}$ of $2 \mathrm{M} \mathrm{NaAct} \mathrm{pH}$ 5.2, followed by $20 \mu \mathrm{L}$ Absolute Ethanol, kept at $-20^{\circ} \mathrm{C}$ for $1 \mathrm{hr}$ and spinned at 10,000 rpm for $10 \mathrm{mins}$, then washed with $70 \%$ ethanol and air dried. This was again suspended in $5 \mu \mathrm{L}$ sterile distilled water and kept at $4^{\circ} \mathrm{C}$ for sequencing.

The PCR sequence product was also purified using $2 \mathrm{M}$ sodium acetate wash technique before the sequencing was run. To $10 \mu \mathrm{L}$ of the PCR product was added $1 \mu \mathrm{L} 2 \mathrm{M} \mathrm{NaAct} \mathrm{pH}$ 5.2, then $20 \mu \mathrm{L}$ Absolute Ethanol and kept at $-20^{\circ} \mathrm{C}$ for $1 \mathrm{~h}$ and subsequently spinned at $10,000 \mathrm{rpm}$ for $10 \mathrm{mins}$, then washed with $70 \%$ Ethanol and air-dried. This was re-suspended in $5 \mu \mathrm{L}$ of sterile distilled water and kept at $4^{\circ} \mathrm{C}$ for sequencing running.

\subsection{Gene Sequencing and Analysis}

The Cocktail mix is a combination of $9 \mu \mathrm{L}$ of Hi di Formamide with $1 \mu \mathrm{L}$ of purified sequence making a total of $10 \mu \mathrm{L}$. The samples were loaded on the ABI machine and the data in form of A, C, T, and G, was released.

Sequence results obtained from above were compared with known sequences in the GenBank using the basic local alignment search tool of the national centre for biotechnology information. Species were identified based on the percentage similarity with the known species sequences in the data base.

\section{Results}

\subsection{Physicochemical Characteristics}

Table 1 shows the physiochemical parameters of surface water and sediments samples of Bodo creek. The pH for water and sediments were 7.68 and 7.87 respectively amongst other parameters as contained in the table.

Table 2 shows the mean of the duplicate colony counts of bacteria isolated from the water and sediment samples. Water samples had more colonies compared to sediment as observed though no significant difference was observed between the counts from water and sediments. $t(4)=2.034(p>0.05)$.

\subsection{Physiological and Biochemical Test}

All the bacterial strains isolated were aerobic and motile and showed varying responses to series of test carried 
Table 1. Physiochemical parameter of Bodo water and sediments samples.

\begin{tabular}{ccc}
\hline Parameters & Water & Sediments \\
\hline $\mathrm{pH}$ & 7.68 & 7.87 \\
Electrical conductivity & $31609 \mu \mathrm{S} / \mathrm{cm}$ & $7240 \mu \mathrm{S} / \mathrm{cm}$ \\
Turbidity & $252 \mathrm{NTU}$ & \\
Salinity & $19.67 \mathrm{ppt}$ & $17.87 \mathrm{ppt}$ \\
Total organic carbon & $3.06 \%$ & $2.20 \%$ \\
Total phosphate & $40.8 \mathrm{mg} / \mathrm{L}$ & $11.15 \mathrm{mg} / \mathrm{kg}$ \\
Total Nitrogen & $673.2 \mathrm{mg} / \mathrm{L}$ & $886.30 \mathrm{mg} / \mathrm{kg}$ \\
Nitrate & $40.6 \mathrm{mg} / \mathrm{L}$ & $37.4 \mathrm{mg} / \mathrm{kg}$ \\
Total petroleum hydrocarbon & $769 \mathrm{mg} / \mathrm{L}$ & $1109 \mathrm{mg} / \mathrm{kg}$ \\
Sulphate & $30.5 \mathrm{mg} / \mathrm{L}$ & $28.46 \mathrm{mg} / \mathrm{kg}$ \\
\hline
\end{tabular}

Table 2. Total heterotrophic bacteria count.

\begin{tabular}{ccc}
\hline & Counts in cfu/mL & \\
\hline Sample & Water & Sediment \\
\hline A & $6.6 \times 10^{4}$ & $5.6 \times 10^{4}$ \\
B & $4.3 \times 10^{4}$ & $2.8 \times 10^{4}$ \\
C & $4.4 \times 10^{4}$ & $1.6 \times 10^{4}$ \\
D & $3.0 \times 10^{4}$ & $3.8 \times 10^{4}$ \\
E & $7.0 \times 10^{4}$ & $5.6 \times 10^{4}$ \\
\hline
\end{tabular}

out on them. Table 3 gives a summary of the physiological and biochemical properties differentiating the isolates. Most of the colonies examined were colorless, circular and some were rod like and smallish.

\subsection{S rRNA Sequencing and Bacterial Identification}

Table 4 and Table 5 shows the molecular identification of the isolates based on 16SrDNA sequences. The PCR amplified fragments had $250 \mathrm{bp}$ in size and generated sequences ranged from 700 to approx. 1500 bp. The 16SrDNA sequence similarity of the isolates to that of previously characterized bacterial species ranged from $86 \%$ to $100 \%$ for bacteria isolates from water samples and $80 \%$ to $99 \%$ for bacteria isolates from sediments.

\section{Discussion}

We studied the diversity of aerobic heterotrophic bacteria present in petroleum hydrocarbon contaminated brackish water and sediment of Bodo creeks. This study became necessary because of the toxic effect of petroleum hydrocarbon components on aquatic life, to establish the existence or otherwise of bacteria and the need for their molecular identification which is rare since the commencement of oil activities in this region to date.

The introduction of 16SrDNA analysis is said to be a useful tool for identifying bacterial species and comparing their biochemical, morphological and physiological properties [23]. Bovin-Jahns et al. [26] opined that the analysis of a small subunit of rDNA sequences for bacteria identification isolated from a natural environment is more efficient compared to the use of phenotypic methods.

From the result of our study, the genus Bacillus dominated the water and sediment samples among other genera like Alcaligenes, Enterobacter, Pseudomonas and Escherichia which are known to be very frequent in sea water and were also isolated from petroleum hydrocarbon polluted aquatic environments in several studies [7] [27].

In bacterial taxonomy, it is common knowledge that two bacteriado not belong to the same species if their 16SrDNA sequence similarity is less than 97\% [28]. In our experiments, isolates M1, M22, BMC1 and AU19157 displayed 86\%, 91\%, 90\% and 86\% identity to the sequences available in the NCBI GenBank for Alcaligenes faecalis, Bacillus cohnii, Bacillus pumilus, Bordetella spp. Similar low identities were observed in 
Table 3. Biochemical and physiological analysis of bacteria isolates.

\begin{tabular}{|c|c|c|c|c|c|c|c|c|c|c|c|c|c|c|c|}
\hline ن் & 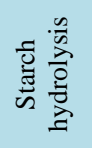 & 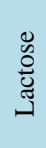 & 苍 & 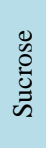 & $\frac{\grave{g}}{\stackrel{\Xi}{\Xi}}$ & 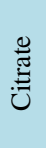 & 胥 & 兄 & $\begin{array}{l}\text { 売 } \\
\text { the }\end{array}$ & 丰 & $\stackrel{\Re}{\Sigma}$ & 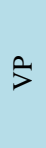 & $\begin{array}{l}\stackrel{0}{\circ} \\
\stackrel{0}{g}\end{array}$ & $\begin{array}{l}\frac{y}{\tilde{\pi}} \\
\frac{\pi}{\tilde{\pi}} \\
\tilde{U}\end{array}$ & 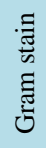 \\
\hline $\mathrm{B}+\mathrm{Cw}$ & + & + & - & + & + & + & + & + & - & - & - & - & - & - & - \\
\hline $\mathrm{B}+\mathrm{Cs}$ & + & + & + & + & + & - & + & + & + & - & - & - & - & - & - \\
\hline Aspink & + & + & + & + & + & + & - & + & + & - & + & - & - & - & + \\
\hline CS & - & - & + & + & - & - & - & + & + & - & - & - & - & - & + \\
\hline FW & + & - & + & + & - & + & + & + & + & - & - & - & - & - & + \\
\hline Kirr & + & + & - & + & + & + & + & - & + & - & + & - & - & + & - \\
\hline SA2 & + & - & + & + & + & - & + & - & + & + & - & - & + & - & + \\
\hline EW & - & + & + & + & + & + & + & + & + & - & + & - & - & - & - \\
\hline FS & + & + & + & + & + & + & - & + & + & - & + & - & - & - & - \\
\hline Jspink & + & + & + & + & + & - & - & + & + & - & + & - & + & - & + \\
\hline Iwirr & + & + & + & - & + & - & + & + & - & - & + & - & - & - & - \\
\hline GW & + & + & + & - & + & + & - & + & + & - & + & - & - & - & + \\
\hline JW & + & + & - & + & + & - & - & - & - & - & - & - & - & + & + \\
\hline K1W & - & - & - & - & + & - & - & - & - & - & - & - & - & + & + \\
\hline BW & - & - & - & - & - & - & - & - & - & - & - & - & + & + & - \\
\hline SD1 & - & + & - & + & + & - & - & - & - & - & - & - & - & + & + \\
\hline $\mathrm{A} 2 \mathrm{w}$ & - & + & + & + & + & + & + & + & + & + & + & + & + & + & + \\
\hline SE1 & + & + & - & + & + & - & - & + & - & - & - & - & - & + & - \\
\hline A2 & - & - & - & - & + & + & + & + & - & - & - & + & - & + & + \\
\hline SW & - & - & - & - & + & - & - & - & - & - & - & - & - & - & + \\
\hline CW & + & + & & - & + & + & - & - & + & + & - & - & + & - & + \\
\hline SW2 & - & + & - & - & - & - & - & - & - & + & + & - & - & - & - \\
\hline JW & - & - & - & - & + & - & - & + & - & - & - & - & - & + & + \\
\hline Sh2 & - & - & - & - & - & - & - & - & - & - & - & - & - & + & - \\
\hline G1w & - & + & + & - & + & + & + & - & - & - & - & - & - & + & + \\
\hline $\mathrm{SJ} 1$ & - & + & + & + & + & - & - & - & - & - & - & - & - & + & + \\
\hline SG2 & - & - & + & + & - & - & + & - & - & - & - & + & + & + & - \\
\hline SH1 & - & + & + & + & + & - & + & + & + & + & - & - & - & + & + \\
\hline \multirow[t]{2}{*}{ SH2 } & + & + & - & - & + & + & - & - & - & - & + & + & - & + & \\
\hline & - & - & + & - & + & - & - & + & + & - & + & - & - & - & - \\
\hline
\end{tabular}

isolates from sediments. These low sequence similarities of suggest that the novel strains may represent new species which is subject to further detailed molecular and physiological studies.

Our studies further isolated bacterial strains with high percentage of similarity ranging from $99 \%$ to $100 \%$ for both water and sediments samples. These include; (Y39), PLW-J 4, INA01087, KUDC1737 which were affiliated to Bacillus pumilus, Bacillus pumilus, Bacillus pumilus, Bacillus aerophilus to for sediment samples. Those isolated from water include: VKK-20L, LLS-M1-17, 44A and P18F04 which were identified as Bacillus pumilus, Bacillus pumilus, Lysinibacillus fusiformis, and Bacillus pumilus respectively. It is however important to note that our experiment did not consider the effect of seasonal variations on the abundance of bacteria isolated though previous studies revealed the effect of seasonal dynamics on the abundance of bacteria strains isolated from a marine environment [29]. Majority of bacteria isolated and identified are mostly Gram-positive which are known to dominate hydrocarbon polluted site, hence this result was expected. 
Table 4. Bacterial isolates from petroleum hydrocarbon polluted brackish water of Bodo creek.

\begin{tabular}{cccc}
\hline Microorganism & Similarity\% & Isolate & Accession number \\
\hline Alcaligenes faecalis & 86 & M1 & KF 056 900.1 \\
Bacillus pumilus & 99 & VKK-20L & KF 717600.1 \\
Bacillus pumilus & 99 & MCC1A08154 & JX680132.1 \\
Myroides odoratimimus & 97 & IHBB1337 & GU186112.2 \\
Bacillus cohnii & 91 & M22 & KC813164.1 \\
Citrobacter murliniae & 98 & 14s (br26) & KF 254752.1 \\
Bacillus pumilus & 99 & LLS-M1-17 & HQ334985.1 \\
Bacillus pumilus & 98 & TKLS-C $4-15$ & HM744710.1 \\
Bordetella sp & 86 & Au19157 & KF601910.1 \\
Lysinibacillus fusiformis & 99 & $44 A$ & KC329831.1 \\
Bacillus pumilus & 90 & BMC1 & KF387715.1 \\
Myroides pelagicus & 97 & AB176662.1 & NR041042 \\
Bacillus pumilus & 100 & P18F04 & JQ833612.1 \\
Enterobacter cloacae & 98 & P45 B06 & JQ832514.1 \\
\hline
\end{tabular}

Table 5. Bacterial isolates from petroleum hydrocarbon polluted brackish sediments from Bodo creek.

\begin{tabular}{cccc}
\hline Sediments & Similarity \% & Isolate & Accession number \\
\hline Bacillus safensis & 99 & Y39 & KF641818.1 \\
Bacillus pumilus & 93 & 1K-MB13-518F & FJ906741.1 \\
Bacillus pumilus & 90 & B34 & KC492105.1 \\
Bacillus pumilus & 99 & PLW-J4-4 & HQ334984.1 \\
Bacillus licheniformis & 91 & P85A08 & JQ835466.1 \\
Cedecea davisae & 91 & HME 8588 & KC201361.1 \\
Emterpbarter hormaechei & 92 & P63E06 & JQ829491.1 \\
Bacillus pumilus & 99 & INA01087 & KF717600.1 \\
Bacillus pumilus & 95 & SSR07 & JQ833773.1 \\
Bacillus subtilis & 85 & P95H01 & JQ832514.1 \\
Enterobacter hormaechei & 81 & P61D018 & JQ829302.1 \\
Bacillus aerophilus & 99 & KUDC 1737 & KC414716.1 \\
Citrobacter freundii & 97 & BAB 1679 & RF535142.1 \\
Psendomonas aeruginosa & 96 & R8-550-1 & JQ659950.1 \\
Bacillus megaterum & 91 & P7H12 & JQ881645.1 \\
Escherichia sp. & 80 & GDR 06 & HE583396.1 \\
\hline
\end{tabular}

The 16SrDNA analysis clearly showed that the bacteria isolated belonged to the respective genera with which they were identified based on the percentage sequence similarity, though when compared to physiological properties some slight differences with respect to some Bacillus strains were revealed. Our isolates labeled as $\mathrm{A}_{2} \mathrm{~W}$, AS, B + Cw and B + Cs stained as Gram-negative rod which is rarely found among aerobic rod shaped bacteria [21] whereas the structure of the cell wall of the bacilli as viewed corresponded with that of a Gram-positive which could explain why this unusual occurrence though their high sequence similarity clearly showed same species affiliation.

\section{Conclusion}

The result of our studies from the characterization of aerobic heterotrophic bacteria from petroleum hydrocarbon 
polluted brackish water of Bodo Greeks suggest that other bacteria from air, marine, fresh water and soil ecosystems can occur in this environment depending probably on the extent of their tolerance to salinity and other intrinsic environmental factors in the creek. The molecular characterization of the bacteria isolated and identified provides evidence of existence of other microorganisms and will serve as baseline data for bacteria diversity of the crude oil contaminated Bodo creek. Further studies on different types of microorganisms and their petroleum hydrocarbon biodegradation potential of both the isolated bacteria and other microbes not investigated in this experiment are suggested.

\section{References}

[1] Kirchman, D.L. (2008) Microbial Ecology of the Oceans. 2nd Edition, John Wiley and Sons Inc., USA. http://dx.doi.org/10.1002/9780470281840

[2] Alexopoulos, A., Plessas, S. and Bezitzoglout, E. (2013) Water Microbial Ecology. An Overview. EOLSS, Orestiada, Greece.

[3] Stager, C.E. and Davis, J.R. (1992) Automated Systems for Identification of Microorganisms. Clinical Microbiology Reviews, 5, 302-327.

[4] Drancourt, M., Bollet, C., Cartioz, A., Martelin, R., Ayial, J.P. and Raoult, D. (2000) 16S Ribosomal DNA Sequence Analysis of a Large Collection of Environmental and Clinical Unidentifiable Bacterial Isolates. Journal of Clinical Microbiology, 38, 1031-1035.

[5] Hagstrom, A., Pomier, T., Rohwer, F., Simi, K., Stolte, W., Sversson, D. and Zweifell, L. (2002) Use of 16S Ribosomal DNA for Delineation of Marine Bacterioplankton Species. Applied Environmental Microbiology, 68, 3628-3633. http://dx.doi.org/10.1128/AEM.68.7.3628-3633.2002

[6] Halpern, B.S., Walbridge, S., Selkpe, K.A., Kappel, C.V., Michel, F., Dagrosa, C., Bruno, J.F., Casey, K.S., Ebert, C., Fox, H.E., Fujita, R., Heinemann, D., Lenihan, H.S., Madin, E.M., Perry, M.T., Selig, E.R., Spalding, M., Steneck, R. and Watson, R.A. (2008) A Global Map of Human Impact on Marine Ecosystem. Science, 319, 948-952. http://dx.doi.org/10.1126/science.1149345

[7] McGenity, T.J., Folwell, B.D., Mckew, R.A. and Sanni, G.O. (2012) Marine Crude Oil Biodegradation: A Central Role for Interspecies Interactions. Aquatic Biosystems, 8, 10. http://dx.doi.org/10.1186/2046-9063-8-10

[8] Agnieszka, C., Katarzyna, P., Kosakowska, A. and Kurlenda, J. (2006) Heterptrophic Bacteria from Brakish Water of the Southern Baltic Sea: Biochemical and Molecular Identification and Characterization. Oceanologia, 48, 525-543.

[9] Cho, J.-C. and Giovannoni, S.J. (2003) Fulvimarina pelagi gen. nov. sp. nov., a Marine Bacterium That Forms a Deep Evolutionary Lineage Descent in the Order Rhizobiales. International Journal of Systematic Evolutionary Microbiology, 53, 1853-1859. http://dx.doi.org/10.1099/ijs.0.02644-0

[10] Ivanova, E.P., Bawman, J.P., Lysako, A.M., Gorshkova, N.M., Kuznetsova, T.A., Kalmovskaya, N.I., Sherchemko, L.S. and Mikhailow, V.V. (2005) Erythobacter vulgaris. A Novel Organism Isolated from the Marine Invertebrates. Systematic Applied Microbiology, 28, 123-130. http://dx.doi.org/10.1016/j.syapm.2004.11.001

[11] Bretta, S.I., Christen, R. and Hope, M.G. (2004) Belliella baltica gen. nov. sp. nov., a Novel Marine Bacteria of the Cytophage-Flavobacterium-Bacteriodes Isolated from Surface Water of the Central Baltic Sea. International Journal of Systematic and Evolutionary Microbiology, 54, 2335-2341.

[12] Pinhassi, J., Wisding, A., Binnerup, S.J., Zweifel, U.L., Ricman, B.Y. and Hagstrom, A. (2003) Spatial Variability in Bacterioplankton Community Composition at the Skagerrak-Kattegat Front. Marine Ecology Progress Series, 255, 1-13. http://dx.doi.org/10.3354/meps255001

[13] Essien, J.P., Benson, N.U. and Antai, P.S. (2008) Application of Correlation Analysis in Assessment of Relationships between Mineral Hydrocarbon Levels and Hydrocarbonoclastic Bacteria Count in Tropical Mangrove Estuary Sediments. Scientific Research and Essays, 3, 94-101.

[14] Bertrand, J.C., Al-Mallah, M., Acquavva, M. and Mille, G. (1990) Biodegradation of Hydrocarbons by an Extremely Halophilic Archaebacterium. Letters in Applied Microbiology, 11, 260-263. http://dx.doi.org/10.1111/j.1472-765X.1990.tb00176.x

[15] Bruns, A. and Berthe-Corti, L. (1999) Fundibacter jadensis gen. nov. sp. nov., a New Slightly Halophilic Bacterium Isolated from Intertidal Sediment. International Journal of Systematic Bacteriology, 49, 441-448.

[16] Gauthier, M.J., Lafay, B., Christen, R., Fernandez, L., Acquaviva, M., Bonin, P. and Bertrand, J.C. (1992) Marinobacter hydrocarbonoclasticus gen. nov., sp. nov., a New Extremely Halotolerant Hydrocarbon-Degrading Marine Bacteria. International Journal of Systematic Bacteriology, 42, 568-576.

[17] Mnif, S., Chamka, M. and Sayadi, S. (2009) Isolation and Characterization of Halomonas sp. Strain C255100, a Hydrocarbon Degrading Bacterium under Hypersaline Condition. Journal of Applied Microbiology, 107, 785-794. 
[18] Sei, A. and Fatherpure, B.Z. (2009) Biodegradation of BTEX at High Salinity by an Enrichment Culture from Hypersaline Sediments of Rozel Point at Great Salt Lake. Journal of Applied Microbiology, 107, 2001-2008.

[19] Cheesebrough, M. (2002) District Laboratory Practice in Tropical Countries 1 \& 2. Cambridge University Press, Cambridge, 614-661.

[20] American Public Health Association (1998) Standard Methods for the Examination of Water and Waste Water. 20th Edition, APHA-AWWA-WPCF, Washington DC.

[21] Kedzia, W. (1990) Microbiological Diagnostics in Medicine. PZWL, Warszawa, 367 p.

[22] Smibert, R.M. and Kreg, N.R. (1994) Phenotypic Characterization. In: Gerhard, P., Murray, R.G., Wood, W.A. and Krieg, N.R., Eds., Methods for General and Molecular Bacteriology, American Society of Microbiology, Washington DC, 611-654.

[23] Cabaj, A., Palinska, K., Kosakowska, A. and Kurlenda, J. (2006) Heterotrophic Bacteria from Brackish Water of Southern Baltic Sea: Biochemical and Molecular Identification and Characterization. Oceanologia, 48, 525-543.

[24] Moore, D.M. and Dowhan, D. (2002) Current Protocols in Molecular Biology. John Wiley and Sons Inc., Hoboken.

[25] Luo, J., Liang, H., Yan, L., Ma, J., Yang, Y.L. and Li, G.B. (2013) Microbial Community Structures in a Closed Raw Water Distribution System Biofilm as Revealed by 454-Pyrosequencing Analysis and the Effect of Microbial Biofilm Communities on Raw Water Quality. Bioresource Technology, 148, 189-195. http://dx.doi.org/10.1016/j.biortech.2013.08.109

[26] Boivin-Johns, V., Bianchi, A., Ruimy, R., Garcin, J., Daumas, S. and Christen, R. (1995) Comparison of Phenotypical and Molecular Methods for Identification of Bacterial Stands Isolated from a Deep Subsurface Environment. Applied and Environmental Microbiology, 61, 3400-3406.

[27] Zobell, C.E. (1946) Marine Microbiology. A Monogram on Hydrobacteriology. Chronica Botanica Co., Waltham, 240 p.

[28] Hagstrom, A., Pinhassi, J. and Zoseifel, U.L. (2000) Biogeographically Diversity among Marine Bacterioplankton Species. Aquatic Microbial Ecology, 21, 231-244. http://dx.doi.org/10.3354/ame021231

[29] Pinhassi, J., Zwerfel, U.L. and Hagstrom, A. (1997) Dominant Marine Bacterioplankton Species Found among ColonyForming Bacteria. Applied and Environmental Microbiology, 63, 3359-3366. 
Scientific Research Publishing (SCIRP) is one of the largest Open Access journal publishers. It is currently publishing more than 200 open access, online, peer-reviewed journals covering a wide range of academic disciplines. SCIRP serves the worldwide academic communities and contributes to the progress and application of science with its publication.

Other selected journals from SCIRP are listed as below. Submit your manuscript to us via either submit@scirp.org or Online Submission Portal.
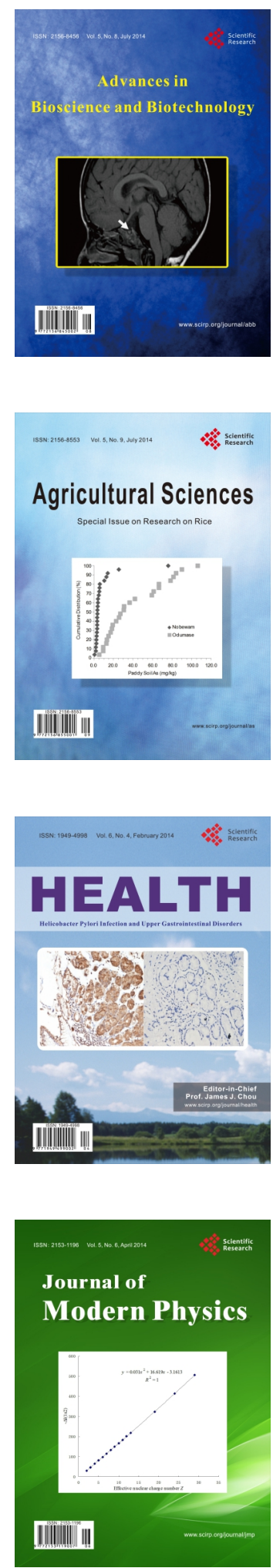
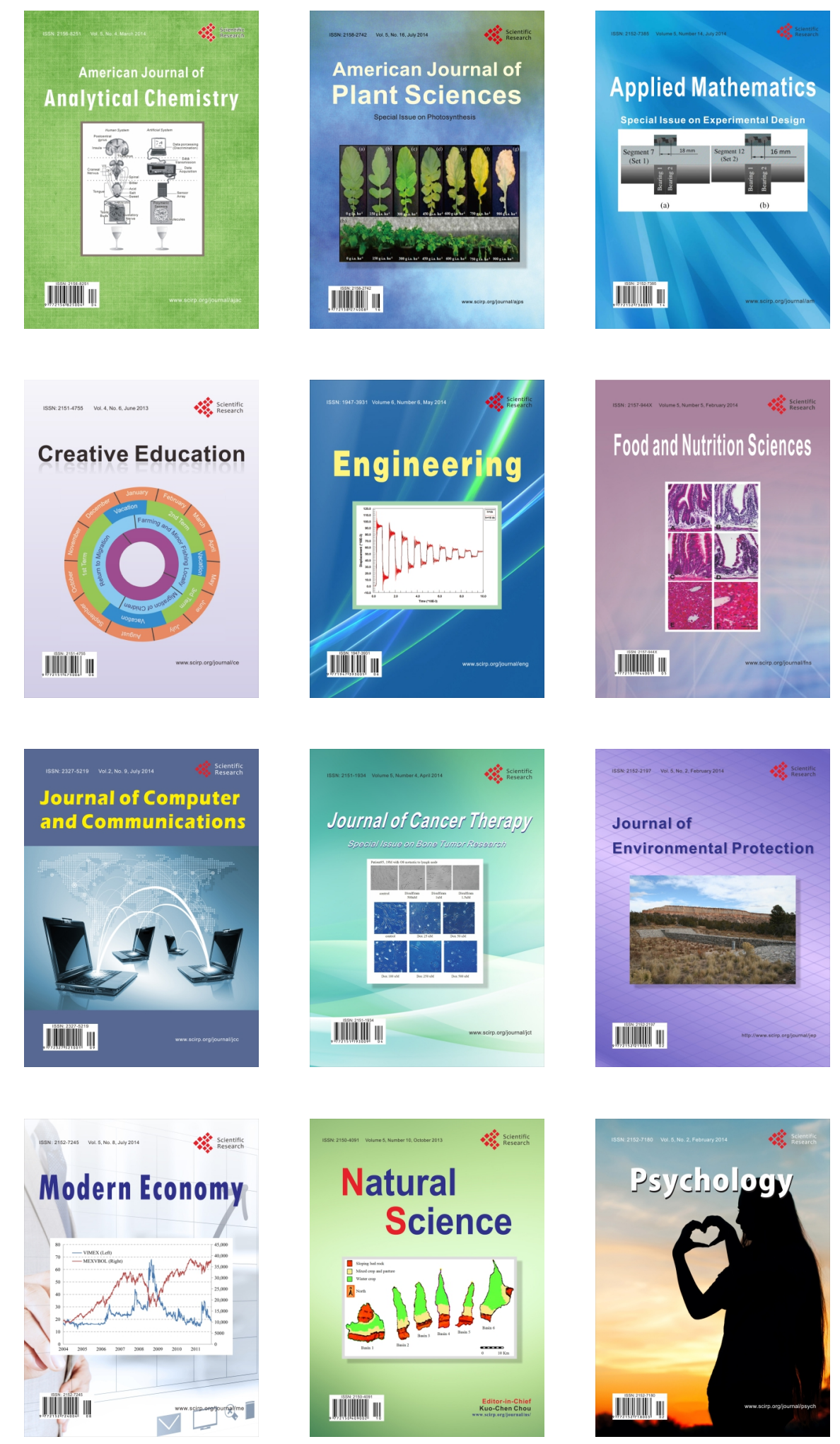